\title{
The Potency of Sugar Palm (Arenga piñata) Household Industry to Contribute Into the Farmer's Income in Sindang Jaya Village, Rejang Lebong
}

\author{
Enggar Apriyanto ${ }^{1.3 *}$, Satria Putra Utama ${ }^{2}$, Putranto Budiono Agung Nugroho ${ }^{1.3}$, \\ Siswahyono ${ }^{1.3}$, and Elnita M Ulina Tarigan ${ }^{1}$ \\ ${ }^{1}$ The Forestry Department of Agricultural Faculty, The Bengkulu University. Jl W.R Supratman, Kandang Limun, \\ Bengkulu 38371, Indonesia \\ ${ }^{2}$ The Social-Economic Department of Agricutural Faculty, Bengkulu University. Jl W.R Supratman, Kandang \\ Limun, Bengkulu 38371, Indonesia \\ ${ }^{3}$ The center of Social forestry, The office of research and community services, The Bengkulu University. Jl W.R \\ Supratman, Kandang Limun, Bengkulu 38371, Indonesia \\ *Corresponding author. Email: satria_pu@yahoo.com
}

\begin{abstract}
Rejang Lebong district is one of the palm sugar producers in Bengkulu Province. The sugar palm (Arenga piñata) household Industry has been establishing for a long time ago. The household industry plays an important role in society's welfare. The aim of the study was to identify the farmer characteristic and calculated the contribution of Arenga piñata household industry to the income of farmers. The study area was at Sindang Jaya Village, Rejang Lebong District because it belongs to villages with high producers of sugar palm. The study had been conducted from March up to May 2016. The methodology was observation and survey with the number of respondents 26 farmers. Collected data were analyzed using simple statistics. The largest percentage of farmers' age ranged from 43-56 years, namely $50.00 \%$, with an average age of the farmers being 48 years. It showed that most sugar palm farmers belonged to the productive age. The largest farmer education level is at the level of education for 6 years, amounting to $46.15 \%$; so it was one of the reasons why the sugar palm farmer has difficulty receiving applied technology dealing with the processing of sugar palm and sugar palm plantation. The total income of sugar palm farmers was about Rp 1,418,621 - Rp 15,312,790 per month, with an average of Rp. 2,933,319.60 per month. The contribution of sugar palm households to the income of sugar palm farmers reached about 58,95\%.
\end{abstract}

Keywords: sugar palm, household industry, contribution, income

\section{INTRODUCTION}

Sugar palm (Arenga pinnata Merr.) is belong to palmae that has many functions, ecological, social and economic value. Sugar palm (Arenga pinnata Merr.) is a type of perennial plant, solitary tree-shaped up to $12 \mathrm{~m}$ in high, diameter at breast height $(\mathrm{DBH})$ up to $60 \mathrm{~cm} \mathrm{[1],} \mathrm{and}$ even up to $20 \mathrm{~m}$ with a leaf crown that rises above the trunk [2]. This plant could grow in wide range of soil quality, clay, mud, and sandy soil. But it can't withstand in acid soil with $\mathrm{pH} \leq 4$. Sugar palm plants will grow well at an altitude between $9-2000 \mathrm{~m}$ above sea level with rainfall of more than $1200 \mathrm{~mm}$ /year. Sugar palm plants need an average temperature of $25 \mathrm{oC}$ for better growth and production. This plant can grow well in mountainous areas, valleys, near rivers, and undulating areas. It is almost found in every area of Indonesia [3]. Sugar palm is generally cultivated in traditional manner by farmer for generations.

Sugar palm is one of the important agricultural commodities that contribute to Gross Regional Domestic Product in Bengkulu Province. The sugar palm has been designated as a regional superior commodity. parts of sugar palm, such as sugar palm black fiber, fruit as a "kolang kaling", sugar palm stick as plate, ethanol, sugar palm powder and sugar could be utilized to fulfill the needs of society. The most valuable product of sugar palm is palm sugar. Palm sugar with its specific aroma, taste, nutritional content, micronutrient nutrients, antioxidants, glycemic index, fiber and good health benefits is in great demand by consumers around the world [4].

Bengkulu Province is one of the largest sugar producers in Indonesia which until now still produces palm. The area of palm sugar was about 2,683.57 ha with palm 
sugar production about 5348.47 tones in 2019 [5]. The palm sugar industry is able to absorb up to $5,488 \mathrm{kk}$ of workers and 9,708 farmers in 2018 [6]. Small palm sugar industries in Bengkulu Province are spread over 5 districts, namely Rejang Lebong, Lebong, Kaur, Bengkulu Tengah, and Kepahyang Regencies [5].

Palm sugar plays an important role in farmer income. Several factors that affected palm sugar production are technology of cultivation, harvesting, and processing of sugar palm sap. Technology of tapping and processing of sugar palm sap into sugar is still done traditionally so that the ability of farmers is limited to develop the palm sugar industry [7]. The aim of the study was to assess the farmer income that be found from palm sugar in Sindang Jaya Village, Rejang Lebong District, Bengkulu Province, Indonesia

\section{MATERIALS AND METHODS}

\section{A. Determination of Research Location}

The study was conducted at Sindang Jaya Village, Rejang Lebong District, Bengkulu Province, Indonesia, since March up to May 2016. Equipment that used during study were questioner kids and camera.

\section{B. Population and Sample}

Sugar palm farmer was designed as the subject of the study. Based on the preliminary survey was found that the population of sugar palm farmer was about 256 farmers. Sampling intensity at the level of 10 percent was used in the study so that the number of sugar palm famer selected as sampling farmer was about 26 farmers. These farmers spread across three sugar palm farmer groups in Sindang Jaya Village.

\section{Data Analysis Methods}

Parameters that were assessed during the study were age, education, income total, and palm sugar income of farmer. Besides that the number of sugar palm tree and tapped sugar palm tree were recorded during the study.

Calculation of the amount of contribution of palm sugar farmers' revenue to total family income uses the formula [8], this income contribution is expressed in percentage $(\%)$.

Contribution $\frac{\text { total revenue of palm sugar farmers } \frac{R p}{B l m}}{\text { total of family revenue } \frac{R p}{B l n}} \times 100 \%$
The revenue contribution is the total revenue from palm sugar with total household income multiplied by $100 \%$. Revenue contribution is the ratio of the gross income of palm sugar farmers received from palm sugar without calculating the costs incurred. Revenue contributions can be categorized based on the categories used in the study [9], namely:

$\begin{array}{lll}\text { 1. } & \text { Very Low } & : 1-20 \% \\ \text { 2. Low } & : 21-40 \% \\ \text { 3. } & \text { Moderate } & : 41-60 \% \\ \text { 4. High } & : 61-80 \% \\ \text { 5. } & \text { Very High } & : \geq 81 \% .\end{array}$

\section{RESULTS AND DISCUSSION}

\subsection{Characteristics of Palm Sugar Farmers in Sindang Jaya Village}

The characteristics of palm sugar farmers in Sindang Jaya Village include; age, education, and number of family members.

Age

The age factor is related to the level of farmer productivity, where the more productive the farmer is, the more he can increase the production of his business activities. According to [10] the productive human age ranges from 15 - 65 years. The age of sugar palm farmers in Sindang Jaya Village ranges from 29 - 70 years. The largest percentage of farmers' age ranged from 43-56 years, namely $50.00 \%$, with an average age of the farmers being 48 years. From Table 1 it is known that the age of sugar palm farmers is still classified as a productive age.

\section{Education}

The education factor is one of the factors supporting the success of farmers in running their farms. The level of education will affect a person's ability to absorb innovation, a broad perspective, and form skills. Based on Table 1, it can be seen that the largest farmer education level is at the level of education for 6 years, amounting to $46.15 \%$ and this shows that the level of education of farmers is relatively low.

\section{Number of Family Members}

The number of family members can provide motivation for farmers as the head of the family, to be able to produce as optimal as possible to meet family needs. Based on Table 1, it can be seen that the average number of farmer family members is 4 people, with details of $26.92 \%$ of $1-3$ family members, and $73.08 \%$ of farmers with $4-7$ families 
Table 1. Socio-demographic Characteristics of Sugar Palm Farmers

\begin{tabular}{|l|l|r|r|c|}
\hline No & \multicolumn{1}{|c|}{ Characteristics } & Range & Average & Persentage \\
\hline \multirow{3}{*}{1} & \multirow{3}{*}{ Age (year) } & $29-42$ & & 30.77 \\
\cline { 3 - 5 } & & $43-56$ & 48.04 & 50.00 \\
\cline { 3 - 5 } 2 & \multirow{3}{*}{2} & $57-70$ & & 19.23 \\
\cline { 3 - 5 } & \multirow{3}{*}{3} & $1-6$ & & 42.31 \\
\cline { 3 - 5 } & \multirow{2}{*}{ Number of Household Members (person) } & $13-12$ & 8.38 & 50.00 \\
\cline { 3 - 5 } & & $1-3$ & & 7.69 \\
\cline { 2 - 5 } & & $4-7$ & 4.38 & 73.08 \\
\hline
\end{tabular}

Source: Primary Data, 2016

\subsection{Economic Characteristics of Palm Sugar Farmers in Sindang Jaya Village}

The economic characteristics of palm sugar business farmers include; land area, number of sugar palm stem, number of tapping stems, and sap water yield.

Table 2. Economic Characteristics of Sugar Palm Farmers

\begin{tabular}{|c|c|c|c|c|}
\hline No & Chacateristics & Range & Average & Percentage \\
\hline \multirow{3}{*}{1} & \multirow{3}{*}{ Land Area (ha) } & $0.5-2.3$ & & 76.93 \\
\hline & & $2.4-4.2$ & 1.95 & 15.38 \\
\hline & & $4.3-6.0$ & & 7.69 \\
\hline \multirow{3}{*}{2} & \multirow{3}{*}{ Number of Sugar Palm Stem (stem) } & $50-200$ & & 88.46 \\
\hline & & $201-350$ & 167 & 7.69 \\
\hline & & $351-500$ & & 3.85 \\
\hline \multirow{3}{*}{3} & \multirow{3}{*}{ Number of Tapping Stems (stem) } & $3-7$ & & 53.84 \\
\hline & & $8-11$ & 7.42 & 34.62 \\
\hline & & $12-15$ & & 11.54 \\
\hline \multirow{3}{*}{4} & \multirow{3}{*}{ Sap Water Yield (liter) } & $20-40$ & & 50.00 \\
\hline & & $41-60$ & 44 & 38.46 \\
\hline & & $61-80$ & & 11.54 \\
\hline
\end{tabular}

Source: Primary Data, 2016

\section{Land area}

The results of the research in Table 2 show that the area of land cultivated by farmers is different, with an average area of 1.95 ha. The majority $(76.93 \%)$ of the land area owned by farmers ranges from $0.5-2.3$ ha. With the difference in the land area owned by each farmer, it is possible that the land area factor becomes an indicator that influences the increase in sugar palm farming production.

\section{Number of Sugar Palm}

The number of sugar palm cultivated by farmers varies, from 50 to 500 sugar palm. From the research results in Table 2, it is known that the average sugar palm farmer has 167 sugar palm plants. The range of the number of plants from 50-200 palm plants per farmer is the largest percentage $(88.46 \%)$, the more the number of sugar palm plants, the optimal production. The results of the study [11], in the Community Forest of Aik Bual, Central Lombok Regency, showed that there were 433 sugar palm scattered in Nyeredet and Agricultural hamlets with the potential for unproductive palm plants of $81.99 \%$. The people of Aik Bual are used as raw material for making palm sugar (divided into; printed sugar, ant sugar, and crystal sugar) as well as by-products in the form of kolang kaling and palm fiber.

\section{Number of Palm Plants That Can Be Tapped}

From Table 2 it is known that the number of sugar palm that can be tapped for each farmer varies, namely 3 to 15 plants, with an average of 7 plants that can be tapped. More than half $(53.84 \%)$ of farmers have palm trees that can be tapped, ranging from 3 - 7 sugar palm. The more the number of sugar palm that are tapped, the more sap is produced.

\section{Sap Water Yield}

The results of the study showed that the average production of palm sap owned by farmers was 44 liters per day. The production range produced by farmers is from 20 
liters to 80 liters per day. Half of the farmers produce palm sap ranging from $20-40$ liters per day. $38.46 \%$ of the farmers produce sap from 41-60 liters per day, while the rest $(11.54 \%)$ of the farmers produce palm sap with a production range of 61-80 liters per day (Table 2). [12] stated that the yield of palm sap production is $10.48 \%$ or processing per liter of fresh sap directly after being derived from the tree produces palm sugar weighing 104.8 grams. This means that with the palm sap produced in Sindang Jaya Village, farmers can produce palm sugar ranging from 2 to $12 \mathrm{~kg}$ of palm sugar per day. Furthermore, the results of research [13] stated that the quality and yield of palm juice that was processed directly was better than the sap that had undergone a storage process, but the yield of sugar produced from the storage process was more.

\subsection{Farmer's House Distance to Land}

The results of the study in Table 3, states that the distance between the farmer's house and the garden varies, namely $0.1-5.0 \mathrm{Km}$, with an average distance of $2.02 \mathrm{Km}$. More than half $(53.85 \%)$ of the distance between the farmer's house and their garden is in the range of 1.8 -3.4 $\mathrm{Km}$, while those who have palm trees close to their house (range $0.10-1.7 \mathrm{~km}$ ) are $42.30 \%$, and the remaining $3.85 \%$ of farmers have palm trees far from their homes with a distance of $3.50-5.00 \mathrm{~km}$.

Table 3. Distance from the home of respondents to their farm area

\begin{tabular}{|c|c|c|c|}
\hline \multirow{3}{*}{ Item } & Range & Average & Percentage \\
\hline \multirow{3}{*}{ Distance from home $(\mathrm{km})$} & $0.10-1,70$ & \multirow{2}{*}{$\mathbf{2}$} & 42.30 \\
\cline { 2 - 2 } & $1.80-3.40$ & $\mathbf{2 . 0 2}$ & 53.85 \\
\cline { 2 - 2 } & $3,50-5.00$ & & 3.85 \\
\hline
\end{tabular}

Source: Primary Data, 2016

\subsection{Palm Sugar Farmer Income}

Palm sugar farmer income includes; acceptance of palm sugar farmer family, total acceptance of palm sugar, and contribution of palm sugar revenue.

\section{Revenue of Palm Sugar Farmer Family}

Table 4 shows the average income of palm sugar farmer families of Rp. 5,541,619.26 per month, with a range of farmers' income of Rp. 1,418,621 - Rp. 15,312,790 per month. The income of palm farmer families in Sindang Jaya Village is mostly in the income range per month of between Rp. 1,418,621 - Rp. 6,050,011 with a percentage of 65.39\%. The income range of Rp. 6,050,012 - Rp. 10,681,402, the amount reached 26.92 percent, while the revenue of $\mathrm{Rp}$. $10,681,403$ - Rp. $15,312,790$ was the smallest with a percentage of $7.69 \%$. The amount of receipt of this palm sugar farmer comes from:

Table 4. Total Amount of Palm Sugar Farmer Family Revenue

\begin{tabular}{|c|c|c|c|c|c|}
\hline No & Revenue & $\begin{array}{l}\text { Number } \\
\text { (Person) }\end{array}$ & Percentage & $\begin{array}{l}\text { Average (IDR/ } \\
\text { month) }\end{array}$ & Range (IDR/ month) \\
\hline 1 & $1,418,621-6,050,011$ & 17 & 65.39 & \multirow{3}{*}{$5,604,520.74$} & \multirow{3}{*}{$8,621-15,312,790$} \\
\hline 2 & $6,050,012-10,681,402$ & 7 & 26.92 & & \\
\hline 3 & $10681.403-15,312790$ & 2 & 769 & & \\
\hline
\end{tabular}

Source: Primary Data, 2016

\section{Revenue of Palm Sugar}

The average income of farmers in Sindang Jaya Village from palm sugar is Rp. 2,933,319.60 per month, with a range of Rp. 1,303,571 - Rp. 5,214,286 per month. Half of the palm sugar farmers' revenue is in the range of Rp. 2,910,717 - Rp. 3,910,716 per month, palm sugar farmer revenue in the range of IDR 1,303,571.43 - IDR $2,607,142.85$ amounted to $38.46 \%$, more than the income of farmers in the range of IDR 3,910,714.29 - IDR $5,214,285.71$ which only amounted to 11.54 percent (Table 5). The results of research [14], in Girirejo Hamlet, Lempake Village, North Samarinda District, found that the level of income generated by craftsmen using coal briquettes is Rp. 2,155,202.38 months, greater than the income of the craftsmen who use firewood, which is Rp. $1,813,889.40$ months 
Table 5. Amount of Palm Sugar Revenue

\begin{tabular}{|c|c|c|c|c|c|}
\hline No & Revenue & $\begin{array}{c}\text { Number } \\
\text { (person) }\end{array}$ & Percentage & $\begin{array}{c}\text { Average (IDR/ } \\
\text { month) }\end{array}$ & Range (IDR/ month) \\
\hline 1 & $1,303,571.43-2,607,142.85$ & 10 & 38.46 & & \\
\hline 2 & $2,607,142.86-3,910,714.28$ & 13 & 50.00 & $2,933,319.60$ & $1,303,571-5,214,286$. \\
\hline 3 & $3,910,714.29-5,214,285.71$ & 3 & 11.54 & & \\
\hline
\end{tabular}

Source: Primary Data, 2016

\section{Contribution of Palm Sugar Revenue}

From Table 6 it can be seen that the contribution of palm sugar revenue on average is $58.94 \%$, with the range of contribution of palm sugar to palm sugar farmer revenue in Sindang Jaya Village of $25.50 \%$ - $95.85 \%$. While the highest contribution range for palm sugar farmers' income was in the range of $48.96 \%-72.41 \%$, the number reached $46.16 \%$. The rest is divided equally, amounting to 26.92 percent each for the range of palm sugar farmers' income in Sindang Jaya Village ranging from $25.50-48.95 \%$ and $72.42-95.85 \%$. In line with the results of the study [15], in the Village of Momalia 1, Posigadan District, Bolaang Mongondow Selatan Regency, it was stated that the average value of clove farming income was greater than the average value outside the agricultural sector and contributed 52.44 percent of total household income. farmers worth IDR $41,030,705.18$ per year. However, it is different from the results of research [16], stating that the household income of farmers in lowland swamps in various land typologies and types of business (type of lebak: bund, middle, and deep) in Ogan Komering Ilir and Ogan Ilir Districts from non-farming, it means that the farm income in bund and deep is still low or still below non-farm income. Each farm contributed to the total household income of farmers, namely the bunds of 63.32 percent and 48.43 percent of deep lebak. Better than the results of the study [17], stated that the contribution of income from community forestry businesses was 7.25 percent, this contribution was classified as low because this work was still a side job with the relatively small land area used.

Table 6. Contribution of Palm Sugar Revenue

\begin{tabular}{|c|c|c|c|c|c|}
\hline No & Contribution (\%) & Amount (person) & Percentage & Average (\%) & Range (\%) \\
\hline 1 & $25.50-48.95$ & 7 & 26.92 & \multirow{2}{*}{58.94} & $25.50-95.85$ \\
\hline 2 & $48.96-72.41$ & 12 & 46,16 & & \\
\hline 3 & $72,42-95,85$ & 7 & 26,92 & & \\
\hline
\end{tabular}

Source: Primary Data, 201

\section{CONCLUSION}

The results of the study found that the average income of palm sugar farmers in Sindang Jaya Village, Rejang Lebong Regency was IDR 5,604,520.74 per month. The contribution of the revenue given by palm sugar to the total family income was $58.94 \%$ on average. This shows that more than half of the contribution that palm sugar gives to family income.

\section{REFERENCES}

[1] P. Ramadani, A. Khaeruddin, and I. Baharuddin, Pengenalan Jenis- Jenis Pohon Yang Umum di Sulaweasi. Palu: UNTAD Press, 2008.

[2] S. Soeseno, Bertanam Aren. Jakarta: PT. Penebar Swadaya, 1991.

[3] Balai Penelitian Tanaman Palma, "Varietas Unggul Aren Genjah Kultim,” 2010.

[4] H. Heriyani., Keutamaan Gula Aren \& Strategi Pengembangan Produk. Lambung Mangkurat University Press, 2016.

[5] Dinas Lingkungan Hidup dan Kehutanan, Hasil Rekapitulasi Data Aren Propinsi Bengkulu. Bengkulu, 2020. 
[6] N. F. Y. Saragih, Suharno, and Harianto, "Analisis Pendapatan Dan Faktor-Faktor Yang Mempengaruhi Pendapatan Pengrajin Gula Aren Di Kabupaten Rejang Lebong Provinsi Bengkulu," Forum Agribisnis, vol. 8, no. 2, pp. 155-168, 2018.

[7] E. Apriyanto and D. Setiadi, "Pengaruh Kondisi Tajuk dan Aplikasi Getar terhadap Produksi Nira Aren di Rejang Lebong Bengkulu," J. Pertan. Trop., vol. 2, no. 2, pp. 177-181, 2016.

[8] U. Hermain, "Alokasi Waktu dan Kontribusi Pendapatan Wanita dalam Rumah Tangga," J. Habonaron Do Bona, vol. 2, pp. 8-9, 2009.

[9] B. Sumantri and A. Budi, "Kontribusi Pendapatan Ibu Rumah Tangga terhadap Pendapatan Keluarga (Studi Kasus; Pemetik Teh di Desa Air Sempiang Kabupaten Rejang Lebong)," J. Agrisep, vol. 2, no. 2, pp. 103-111, 2004.

[10] P. Simanjutak, Pengantar Ekonomi Sumber Daya Manusia. Jakarta: Lembaga Penerbit Fakultas Ekonomi UI, 2001.

[11] K. Webliana and D. S. Rini, "Potensi dan Pemanfaatan Tanaman Aren (Arenga Pinnata) di Hutan Kemasyarakatan Aik Bual Kabupaten Lombok Tengah," J. AGROHITA, vol. 5, no. 1, pp. 25-35, 2020.

[12] M. Lempang, "Rendemen dan Kandungan Nutrisi Nata Pinnata yang Diolah dari Nira Aren," J.
Penelit. Has. Hutan, vol. 24, no. 2, pp. 133-144, 2006.

[13] Baharuddin, M. Muin, and H. Bandaso, "Pemanfaatan Nira Aren (Arenga pinnata Merr) Sebagai Bahan Pembuatan Gula Putih Kristal," J. Perenn., vol. 3, no. 2, pp. 40-43, 2007

[14] D. Sopiannur, R. Mariati, and Juraemi, "Studi Pendapatan Usaha Gula Aren Ditinjau dari Jenis Bahan Bakar di Dusun Girirejo Kelurahan Lempake Kecamatan Samarinda Utara (Study," Jurnal EPP, vol. 8, no. 2, pp. 34-40, 2011.

[15] Y. Malahika, Y. Saleh, and A. Murtisari, "Kontribusi Usahatani Cengkeh Terhadap Pendapatan Rumah Tangga Petani di Desa Momalia 1 Kecamatan Posigadan Kabupaten Bolaang Mongondow Selatan," J. AGRINESIA, vol. 2, no. 3, pp. 210-218, 2018.

[16] Nasir, I. Zahri, A. Mulyana, and Yunita, "Analisis Struktur dan Distribusi Pendapatan Rumah Tangga Petani di Lahan Rawa lebak," J. Agrisep, vol. 14, no. 1, pp. 97-107, 2015.

[17] Musdi, Hardjanto, and L. Sundawati, "Kontribusi Hutan Rakyat terhadap Pendapatan Petani di Kecamatan Kabawo Kabupaten Muna.,” J. Penelit. Kehutan. Bonita Vol., vol. 2, no. 2, pp. 1-8, 2020. 